\title{
Historical and projected precipitation extremes over Pare watershed in Arunachal Pradesh, India
}

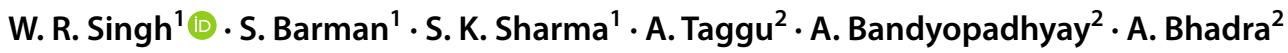

Received: 8 September 2020 / Accepted: 9 February 2021 / Published online: 19 March 2021

(c) The Author(s) 2021

\begin{abstract}
The aim of this paper is to understand the historical and future climate change situation using 15 extreme precipitation indices in the Pare watershed of Arunachal Pradesh, India. Historical period (1981-2019) and future period (2021-2050) precipitation data are used to compute extreme precipitation indices in RClimDex software. The Pare watershed was divided into 13 subwatersheds; however, the results of the study showed no significant spatial variation. This study found that majority of the precipitation extreme indices are showing decreasing trends during the historical period and most of them are statistically insignificant at 95\% confidence level. Only three indices such as SDII, CWD and MRI are found significant at 0.05 level in the Pare watershed. Though not significant, the annual precipitation amount in the Pare watershed was found decreasing at the rate of $3.3 \mathrm{~mm}$ per year during the study period. The trend analysis over the whole watershed indicated significant decreasing trends for CWD and MRI while indicating significant increasing trend for SDII. The representative concentration pathway (RCP) 4.5 and 8.5 projected the extreme precipitation indices in a very similar way. The results of the trend analysis under RCP 8.5 showed significant decreasing trend only at SW10 for the index-moderate rainfall index (MRI). Various cases of RX1DAY and RX5DAY not falling during the months of monsoon were observed in both the historical and future periods. The percentage departures of the monsoon from its annual total had increased in RCP 4.5 and RCP 8.5 scenarios as compared to the historical periods. The results of this climatic investigation suggest that the precipitation regime in the study area had been accompanied and also expected by overall reduction in precipitation amount, milder rainfall events, reduction in monsoon (June-September) rainfall and drier climatic conditions. With the prevalent historical scenario and future projected scenarios of the extreme precipitation indices, the water resource potential in the study area is expected to be greatly reduced, for which the authors seek the attention of various stakeholders in water and allied sectors to come together and discuss on the construction of water conservation structures so that agricultural activities can be expanded and remain sustainable.
\end{abstract}

Keywords Extreme precipitation indices $\cdot$ RClimDex $\cdot$ Representative concentration pathway $\cdot$ Trends $\cdot$ Monsoon

\section{Introduction}

The changing pattern of rainfall affects the availability of freshwater as well as the food production (Dore 2005), and therefore it calls for immediate and systematic attention. A $1{ }^{\circ} \mathrm{C}$ rise in temperature throughout the growing period of wheat will reduce its production by about 4-5 million tonnes (Aggarwal 2008). Changes in rainfall

W. R. Singh

wrsingh.nihr@gov.in

1 Centre for Flood Management Studies, NIH-Guwahati, Guwahati, Assam 781006, India

2 North Eastern Regional Institute of Science and Technology, Nirjuli, Itanagar, Arunachal Pradesh 791109, India amount, spatial and temporal distribution would affect the spatial and temporal distribution of runoff, surface water resource, soil moisture and groundwater reserves which would ultimately influence the occurrence of floods and droughts. Gosain et al. (2006) quantified the impact of climate change on the water resource of various Indian river basins and reported that availability of freshwater in many river basins in India would decrease due to change in climate. Almost over 70\% of the annual rainfall in India is concentrated during the four monsoon months (June-September) leading to scarcity of water in many parts of the country during the other nonmonsoon months. In the northeastern part of India, a decreasing trend in summer monsoon rainfall was observed (Rupakumar et al. 1992). Patra et al. (2012) identified a long-term insignificant 
declining trend in annual as well as monsoon rainfall, and increasing trends in the post-monsoon, winter and summer seasons in the state of Orissa during the period from 1871 to 2006.

Extreme weather or climate events when they occurred bring devastating effects to the society, economy and environment (Mirza 2003; Guan et al. 2015; Santos and Oliveira 2017). Obasi (1994) reported that disasters due to extreme meteorological events contribute approximately $85 \%$ of all the natural disasters in the world. Natural disasters are not just a variation in climatic means, they are mostly due to extreme events (Plummer et al. 1999). Keggenhoff et al. (2014) stated that the changing trends of climate extremes required greater attention than trends of climatic means as such extreme events are more intensive and brings catastrophes. Therefore, before any studies involving climate change and its impact, studies on extreme indices are necessary. Germanwatch - an independent Berlin-based development and environmental organization, publishes global climate risk index (CRI) of all the countries based on the vulnerability to extreme weather events and associated socioeconomic data such as number of deaths per 100,000 inhabitants, extent of financial losses and loss per unit of gross domestic products (GDP). They also published the ranks of all the countries, with higher rank meaning frequent and more catastrophes events. According to its report, India was ranked sixth (Eckstein et al. 2018) and 14th (Eckstein et al. 2019) respectively in the years 2016 and 2017.

The Expert Team on Climate Change Detection, Monitoring and Indices (ETCCDMI) sponsored by WMO (World Meteorological Organization) Commission for Climatology (CCI) and the Climate Variability and Predictability Project (CLIVAR) has identified 27 core indices that represent a common guideline for regional analysis of climate. These indices are based on daily temperature and precipitation data and are actively used in various studies (Kim et al. 2011; Al Al-Al-Habsi et al. 2014; Badsha et al. 2016; Toure et al. 2017; Santos and Oliveira 2017). Keggenhoff et al. (2014) found that in Georgia, summer days, frost days and tropical nights have increased significantly between 1971 and 2010, while the trends in precipitation-based extreme indices are not significant although they are found to have an increasing trend. In context to India, a study conducted by Tirkey et al. (2018) found that in Jharkhand, the average consecutive dry days have increased during the study period. Various similar recent studies conducted to find out the variability and trends in both precipitation and temperature data in India include Roy and Balling (2004), Rajeevan et al. (2008), Kothawale et al. (2010), Revadekar et al. (2012), Singh et al. (2015), Shrestha et al. (2017) and Dubey and Sharma, (2018). In the present study, temporal changes and trends in precipitation extremes over the Pare watershed, Arunachal Pradesh, India, are analyzed using RClimDex tool (Zhang and Yang 2004).

\section{Study area and data}

The Pare watershed is one of the eastern Himalayan watersheds formed on the river Pare which is a subtributary of Brahmaputra river. It is located in Papumpare district of Arunachal Pradesh, India. The boundaries of the Pare watershed lie between $93^{\circ} 13^{\prime} 15^{\prime \prime} \mathrm{E}$ and $93^{\circ} 47^{\prime} 07^{\prime \prime} \mathrm{E}$ longitudes and $27^{\circ} 09^{\prime} 36^{\prime \prime} \mathrm{N}$ and $27^{\circ} 22^{\prime} 08^{\prime \prime} \mathrm{N}$ latitudes covering a geographical area of $773.5 \mathrm{sq}$. km. The outlet of the watershed is situated at $\operatorname{Hoj}\left(93^{\circ} 47^{\prime} 7.92^{\prime \prime} \mathrm{E}\right.$ and $27^{\circ}$ $15^{\prime} 18.24^{\prime \prime} \mathrm{N}$ ), as shown in Fig. 1 along with river network and its 13 subwatersheds. Pare watershed is a mountainous watershed where the hill ridges are situated haphazardly as hill ridges start either parallelly or in opposite direction as soon as one hill ridges end. Due to this typical topography, the rivers are highly undulated. The climate of the northeastern region of India where the study area falls is predominantly influenced by the precipitation during monsoon season (June to September) accompanied by some premonsoonal showers and periodic events of convective precipitations (Kumar and Dimri 2018). The annual average rainfall during 1981-2019 in the Pare basin was $2731 \mathrm{~mm}$.

In the present study, gridded datasets of precipitation for the period from 1981 to 2019 were acquired from India Meteorological Department (IMD). In total, 15 grid points for precipitation as shown in Fig. 1 were selected for analysis. The spatial resolution of the gridded precipitation used in the study is $0.25^{\circ} \times 0.25^{\circ}$. Bandyopadhyay et al. (2018) compared the IMD gridded precipitation data with observed station data over various parts of India including the northeastern part of India from 1971 to 2010 . Their analysis showed that IMD gridded data performed better than other gridded precipitation products obtained from Global Precipitation Climatology Project (GPCP), Coordinated Regional Climate Downscaling Experiment (CORDEX) and National Centers for Environment Predictors (NCEP). The monthly variation of precipitation in the study area is shown in Fig. 2. Majority of the annual precipitation occurred during the monsoon season, i.e., from June to September. The premonsoon months of April and May received abundant rainfall and are usually higher than post-monsoon months of October and November. The Pare watershed received rainfall highest in the month of July. For the future period (2021-2050), Coordinated Regional Downscaling Experiment (CORDEX) precipitation scenarios from the model RegCM4-4 driven by the model MPI-MMPI-ESM-MR belonging to the r1ilp1 ensemble family given by Indian Institute of Tropical Meteorology, Pune, India, are downloaded from the website https://esgfnode. 1lnl.gov/projects/esgf-1lnl/. The downloaded data include 

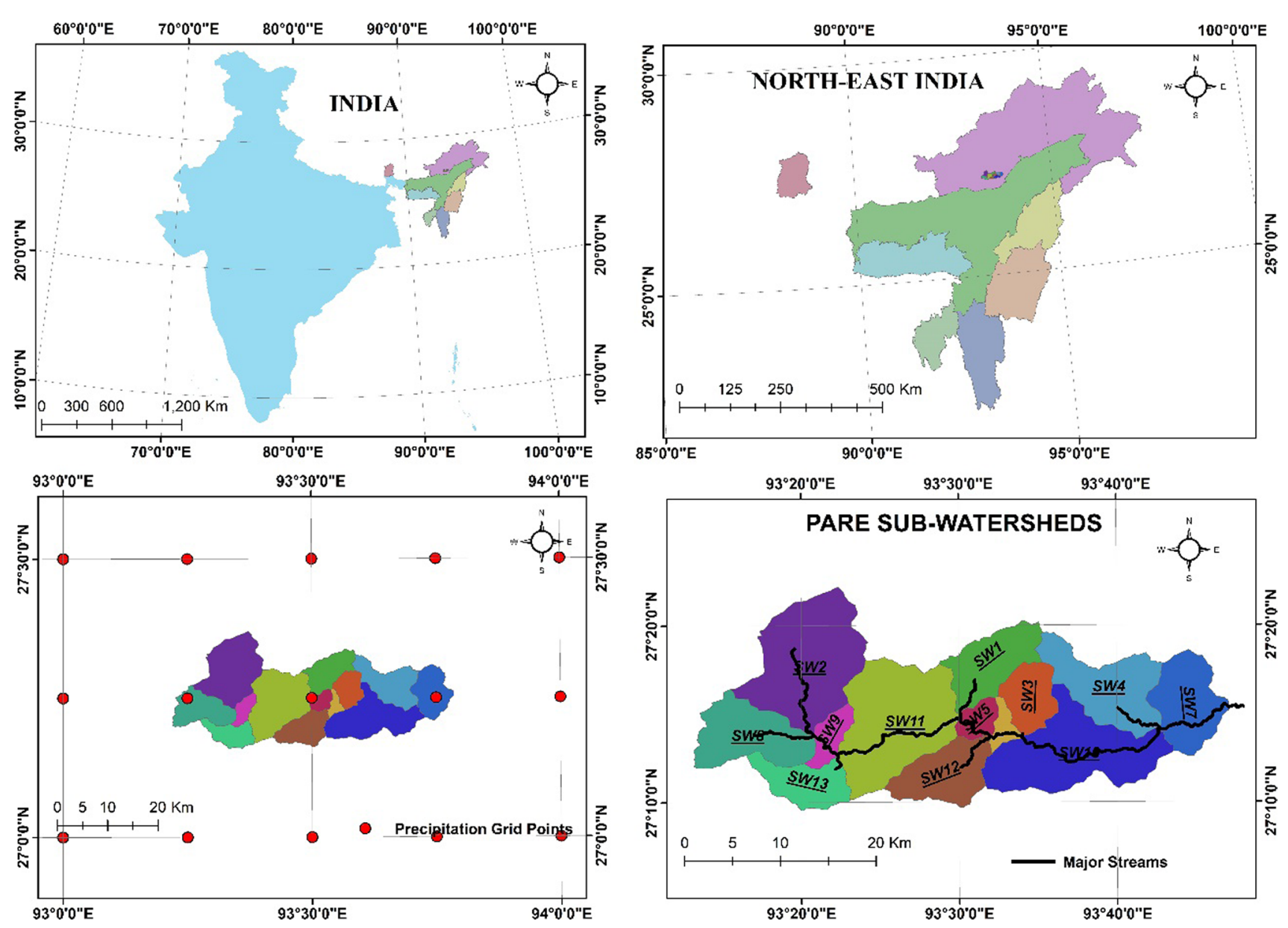

Fig. 1 Map of the study area-Pare watershed and its 13 subwatersheds

Fig. 2 Monthly variation in precipitation in the study area

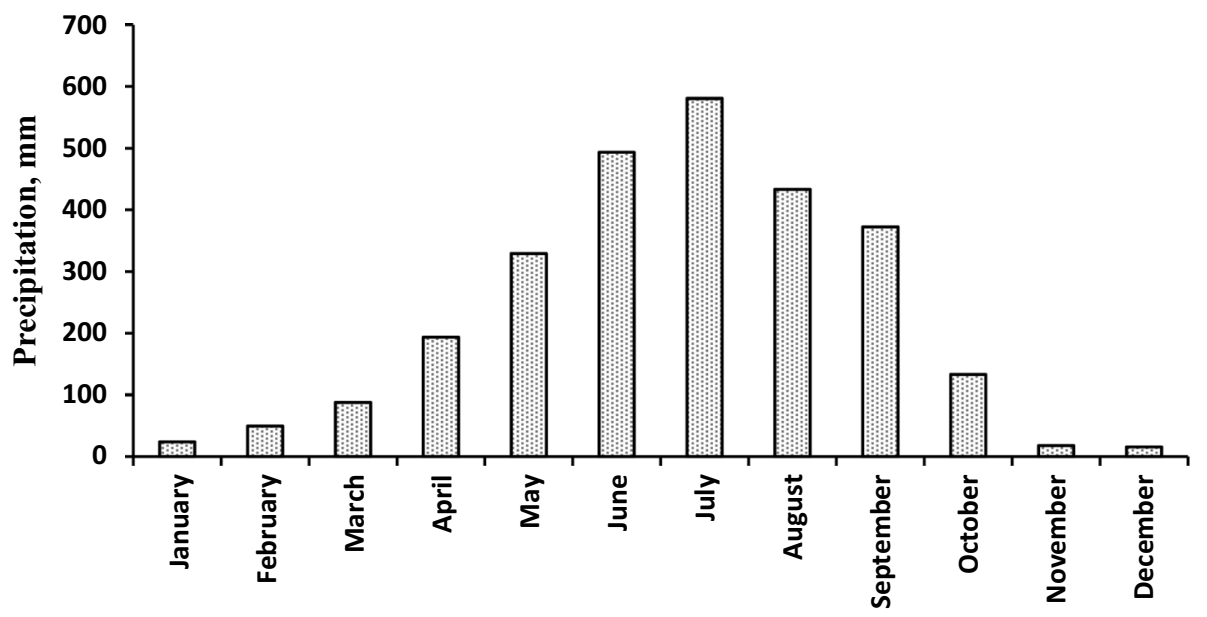

Months

historical (1981-2005) and two radiative forcing from representative concentration pathway (RCP) scenarios namely-RCP4.5 and RCP 8.5 for a period of 2021-2050.
The historical simulation was required for bias correction of the future projected precipitation scenarios to reduce the uncertainties in the assessment studies. 


\section{Methodology}

\section{Preparation of input data}

A MATLAB program was framed to convert from. grd format of IMD raw gridded data to time series in.xlsx format for 15 precipitation grid points. Another program based on python language was also framed to split and convert the time series to daily precipitation and temperature in ASCII format. Using the capability of model builder in ArcGIS, processes such as creation of point shapefiles, interpolation using inverse distance weighting (IDW) technique, extraction of values for 13 subwatersheds of Pare in table format and conversion of these tables into excel files (in. xlsx format) were performed. Another Python program to merge these daily data into 13 time series was framed. Finally, the time series are converted to ASCII which is the required format to run RClimDex. A flow diagram of the methodology followed in the study is shown in Fig. 3.

Simulated climate data are usually subjected to biases when compared to observational data (Ehret et al. 2012). This departure of values from observational data may alter the results of any study. In view of the importance of bias correction, a delta with multiplicative approach was used to correct biases in future precipitation scenarios.
The delta method maps the differences between observed and simulated values, and therefore this method assumes biases to be specific to locations (Maraun and Widmann 2018). Debias precipitation values for both RCPs $(4.5$ and 8.5) are simulated in a software CMhyd (Rathjens et al. 2016) using simulated historical data of 25 years (1981-2005) and observed precipitation data from 15 IMD grids. The outputs from the operation of CMhyd software were than processed to give time series data for each subwatershed as explained above.

\section{Determination of precipitation extremes}

Using the ASCII files prepared above, a total of 15 precipitation-based extreme indices were computed using RClimDex software (Zhang and Yang 2004) for understanding the change in precipitation regime during the study periods. These indices are selected considering that they are sufficient and relevant to cover different aspects of precipitation such as amount, duration and intensity in the study area. All the indices and their definition computed in this study are illustrated in Table 1. The precipitation extremes for the whole watershed were computed using average precipitation over the 13 subwatersheds.

The RClimDex software also results in monthly RX1DAY and RX5DAY values. From the monthly values, RX1DAY
Fig. 3 Flow diagram of the methodology adopted in the study

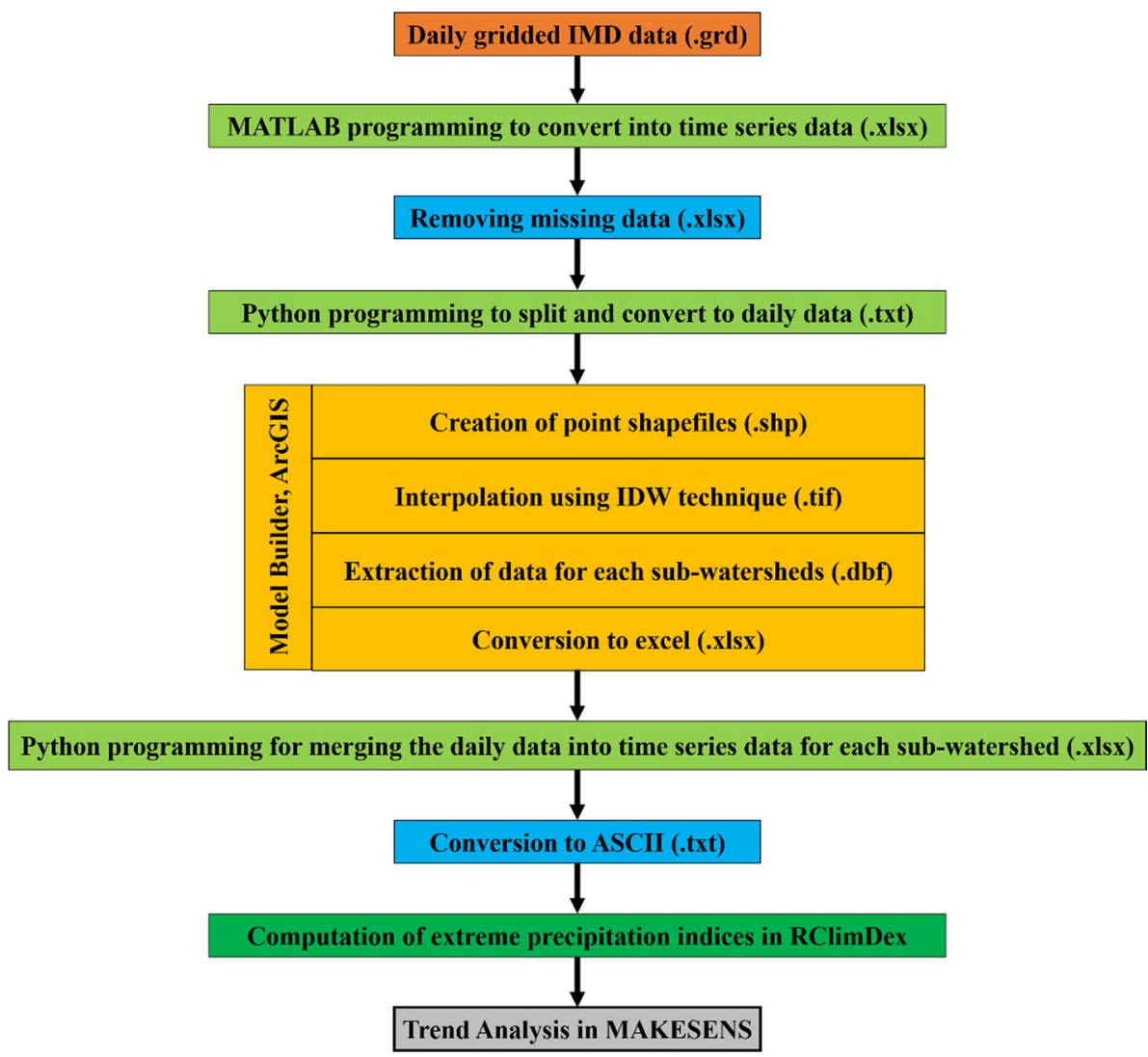


Table 1 Extreme precipitation indices determined in the study

\begin{tabular}{|c|c|c|c|}
\hline Index & Descriptive name & Definitions & Units \\
\hline RX1DAY & Max 1-day precipitation amount & Annual maximum 1-day precipitation & $\mathrm{mm}$ \\
\hline RX5DAY & Max 5-day precipitation amount & Annual maximum consecutive 5-day precipitation & $\mathrm{mm}$ \\
\hline SDII & Simple daily intensity index & $\begin{array}{l}\text { Annual total precipitation divided by the number of wet days (defined as } \\
\text { days when daily precipitation, } \mathrm{PRCP} \geq 1.0 \mathrm{~mm} \text { ) in the year }\end{array}$ & $\mathrm{mm} /$ day \\
\hline $\mathrm{R} 10$ & - & Annual count of days when PRCP $\geq 10 \mathrm{~mm}$ & days \\
\hline $\mathrm{R} 25$ & - & Annual count of days when PRCP $\geq 25 \mathrm{~mm}$ & days \\
\hline CDD & $\begin{array}{l}\text { Consecutive days } \\
\text { Dry }\end{array}$ & Maximum number of consecutive days with daily rainfall $(\mathrm{RR})<1 \mathrm{~mm}$ & days \\
\hline CWD & $\begin{array}{l}\text { Consecutive days } \\
\text { Wet }\end{array}$ & Maximum number of consecutive days with $\mathrm{RR} \geq 1 \mathrm{~mm}$ & days \\
\hline PRCPTOT & Annual total wet-day precipitation & Annual total PRCP in wet days $(\mathrm{RR} \geq 1 \mathrm{~mm})$ & $\mathrm{mm}$ \\
\hline RX1DAY (monsoon) & - & Maximum 1-day precipitation during monsoon months & $\mathrm{mm}$ \\
\hline RX5DAY (monsoon) & - & Maximum consecutive 5-day precipitation during monsoon months & $\mathrm{mm}$ \\
\hline MRI & Moderate Rainfall Index & Annual count of days when PRCP is between 10 and $25 \mathrm{~mm}$ & days \\
\hline HRI & High Rainfall Index & Annual count of days when PRCP is between 25 and $75 \mathrm{~mm}$ & days \\
\hline $\mathrm{R} 75$ & Very High Rainfall Index & Annual count of days when PRCP $\geq 75 \mathrm{~mm}$ & days \\
\hline $\mathrm{R} 50$ & - & Annual count of days when $\mathrm{PRCP} \geq 50 \mathrm{~mm}$ & days \\
\hline R100 & - & Annual count of days when PRCP $\geq 100 \mathrm{~mm}$ & days \\
\hline
\end{tabular}

(monsoon) and RX5DAY (monsoon) are calculated by taking the maximum of the June to September values. MRI is calculated by subtracting R25 from R10, while HRI is calculated by subtracting R75 from R25. More details about the indices in Table 1 can be obtained in Zhang and Yang (2004).

\section{Trend analysis of extreme precipitation indices}

The trend analysis of extreme precipitation indices was done in MAKESENS (Salmi et al. 2002) which is an excel template for detection and estimation of trends in the time series. The procedure in the template is based on the nonparametric Mann-Kendall test (Mann 1945; Kendall 1975) for the trend and the nonparametric Sen's slope method for the magnitude of the trend (Sen 1968). Mann-Kendall detects the presence of a monotonic trend either increasing or decreasing in the time series with no seasonal or other cycle, while Sen's slope method gives the magnitude for the trend using a linear model. Macrocode, details of the procedure and user's manual are provided in Salmi et al. (2002).

\section{Results and discussion}

\section{Precipitation extremes during 1981-2019}

The Mann-Kendall test $Z$ and Sen's slope $Q$ values for different extreme precipitation indices are illustrated in Table 2. Majority of the precipitation extreme indices indicated falling trends, and majority are found statistically insignificant at 0.05 level. Statistically significant trends are observed in indices such as SDII, CDD, CWD and MRI. The annual total precipitation indicated by PRCPTOT has shown falling trends in every subbasin as whole as the whole watershed (Pare). Although the results are not statistically significant at 0.05 level, the annual precipitation is found decreasing at a rate of $3.3 \mathrm{~mm}$ per year in the Pare watershed. The trend of SDII at each subwatershed is found rising indicating rainfall intensities in the area. Also, the trend of SDII in Pare watershed is found significantly increased during the period of 1981-2019. The trend of consecutive dry days (CDD), though found increasing in all the subwatersheds, is statistically significant in SW7 at the rate of 0.3 days per year. On the contrary, consecutive wet days (CWD) exhibits significant decreasing trends in all subwatersheds except in SW5, SW9 and SW12. Precipitation extremes such as RX1DAY, RX5DAY, R10 and RX5DAY (monsoon) are found decreasing though statistically insignificant at 0.05 level. The moderate rainfall index (MRI) is found to be decreasing significantly at all the subwatersheds except SW7 and SW8. However, high rainfall index (HRI), though statistically insignificant at 0.05 level, is found to be increasing at all subwatersheds except SW7. On the other hand, trends in very high rainfall index (R75) indicated decreasing trends for majority of the subwatersheds. The overall trends of Pare watershed indicated statistically significant increasing trends for the index SDII and negative trends for the indices CWD and MRI. 
Table 2 Trend directions and magnitudes for various precipitation extremes during 1981-2019

\begin{tabular}{|c|c|c|c|c|c|c|c|c|c|c|c|c|c|c|}
\hline Indices & SW1 & SW2 & SW3 & SW4 & SW5 & SW6 & SW7 & SW8 & SW9 & SW10 & SW11 & SW12 & SW13 & Pare \\
\hline \multicolumn{15}{|c|}{$R X 1 D A Y$} \\
\hline Z & -0.6 & -0.5 & -0.5 & 0.0 & -0.9 & -0.6 & -0.3 & -0.7 & -0.7 & 0.0 & -0.7 & -0.6 & -0.5 & 0.8 \\
\hline Q & -0.2 & -0.2 & -0.2 & 0.0 & -0.5 & -0.2 & -0.2 & -0.2 & -0.2 & 0.0 & -0.3 & -0.2 & -0.2 & 0.3 \\
\hline \multicolumn{15}{|c|}{$R X 5 D A Y$} \\
\hline Z & -1.2 & -0.8 & -1.1 & -0.9 & -1.3 & -1.2 & -1.0 & -0.9 & -1.0 & -0.9 & -1.1 & -1.2 & -0.9 & 0.1 \\
\hline Q & -1.2 & -1.0 & -1.0 & -0.7 & -1.4 & -1.2 & -0.8 & -1.0 & -0.9 & -0.6 & -1.1 & -1.2 & -0.8 & 0.2 \\
\hline \multicolumn{15}{|l|}{ SDII } \\
\hline $\mathrm{Z}$ & 1.2 & 1.4 & 1.0 & 1.5 & 1.0 & 1.1 & 1.4 & 1.1 & 1.4 & 1.2 & 1.1 & 1.0 & 1.2 & 2.4 \\
\hline Q & 0.0 & 0.1 & 0.0 & 0.0 & 0.0 & 0.0 & 0.0 & 0.1 & 0.1 & 0.0 & 0.0 & 0.0 & 0.1 & 0.1 \\
\hline \multicolumn{15}{|l|}{$R 10$} \\
\hline $\mathrm{Z}$ & -1.5 & -0.8 & -1.5 & -1.8 & -1.2 & -1.5 & -1.7 & -0.3 & -0.8 & -1.7 & -1.3 & -1.5 & -0.8 & -1.6 \\
\hline Q & -0.2 & -0.2 & -0.3 & -0.3 & -0.2 & -0.2 & -0.2 & -0.1 & -0.2 & -0.3 & -0.2 & -0.3 & -0.2 & -0.3 \\
\hline \multicolumn{15}{|l|}{$R 25$} \\
\hline Z & 0.4 & 0.5 & 0.3 & 0.1 & 0.5 & 0.5 & -0.7 & 0.3 & 0.4 & 0.0 & 0.3 & 0.2 & 0.3 & 0.7 \\
\hline Q & 0.1 & 0.1 & 0.0 & 0.0 & 0.1 & 0.1 & -0.1 & 0.1 & 0.1 & 0.0 & 0.0 & 0.0 & 0.0 & 0.1 \\
\hline \multicolumn{15}{|l|}{$C D D$} \\
\hline Z & 1.2 & 1.3 & 1.4 & 1.8 & 0.6 & 1.2 & 2.1 & 0.8 & 1.8 & 1.4 & 1.1 & 1.1 & 1.2 & 1.5 \\
\hline Q & 0.2 & 0.1 & 0.2 & 0.3 & 0.1 & 0.2 & 0.3 & 0.1 & 0.2 & 0.2 & 0.2 & 0.2 & 0.1 & 0.2 \\
\hline \multicolumn{15}{|l|}{$C W D$} \\
\hline Z & -3.5 & -2.6 & -3.1 & -3.8 & -1.5 & -2.8 & -2.4 & -2.1 & -1.8 & -3.4 & -2.1 & -1.9 & -2.1 & -3.8 \\
\hline Q & -0.5 & -0.4 & -0.5 & -0.7 & -0.2 & -0.4 & -0.3 & -0.2 & -0.3 & -0.6 & -0.3 & -0.3 & -0.3 & -0.7 \\
\hline \multicolumn{15}{|c|}{ PRCPTOT } \\
\hline $\mathrm{Z}$ & -0.9 & -0.3 & -1.0 & -1.2 & -0.8 & -0.9 & -1.1 & -0.1 & -0.6 & -1.3 & -0.7 & -0.8 & -0.3 & -0.3 \\
\hline Q & -7.9 & -1.9 & -9.5 & -8.4 & -5.9 & -7.5 & -7.5 & -1.4 & -3.0 & -7.6 & -5.7 & -6.0 & -2.5 & -3.3 \\
\hline \multicolumn{15}{|c|}{$R X 1 D A Y$ (monsoon) } \\
\hline $\mathrm{Z}$ & 0.0 & 0.0 & -0.1 & 0.3 & 0.1 & 0.2 & -0.3 & 0.2 & 0.0 & 0.3 & 0.0 & 0.1 & 0.3 & 1.0 \\
\hline Q & 0.0 & 0.0 & 0.0 & 0.1 & 0.1 & 0.1 & -0.2 & 0.1 & 0.0 & 0.1 & 0.0 & 0.0 & 0.1 & 0.4 \\
\hline \multicolumn{15}{|c|}{$R X 5 D A Y$ (monsoon) } \\
\hline Z & -0.9 & -0.5 & -0.9 & -0.7 & -0.9 & -0.9 & -1.1 & -0.5 & -0.4 & -0.7 & -0.8 & -1.0 & -0.4 & 0.2 \\
\hline Q & -0.7 & -0.5 & -0.7 & -0.5 & -1.0 & -0.7 & -0.9 & -0.4 & -0.4 & -0.5 & -0.7 & -0.8 & -0.4 & 0.2 \\
\hline \multicolumn{15}{|l|}{$M R I$} \\
\hline $\mathrm{Z}$ & -3.1 & -2.8 & -3.1 & -3.4 & -2.4 & -3.2 & -1.8 & -0.8 & -2.3 & -2.9 & -2.6 & -2.6 & -2.2 & -3.7 \\
\hline Q & -0.3 & -0.2 & -0.3 & -0.3 & -0.2 & -0.3 & -0.2 & -0.1 & -0.2 & -0.2 & -0.3 & -0.3 & -0.2 & -0.4 \\
\hline \multicolumn{15}{|l|}{$H R I$} \\
\hline Z & 0.6 & 0.5 & 0.5 & 0.2 & 0.7 & 0.6 & -0.8 & 0.7 & 0.5 & 0.1 & 0.4 & 0.5 & 0.5 & 0.4 \\
\hline Q & 0.1 & 0.1 & 0.1 & 0.0 & 0.1 & 0.1 & -0.1 & 0.1 & 0.1 & 0.0 & 0.1 & 0.1 & 0.1 & 0.1 \\
\hline \multicolumn{15}{|l|}{$R 75$} \\
\hline $\mathrm{Z}$ & -0.5 & -0.1 & 0.1 & -0.1 & -1.0 & -0.7 & 0.0 & -0.6 & 0.0 & 0.4 & -0.6 & -0.4 & -0.3 & 1.6 \\
\hline $\mathrm{Q}$ & 0.0 & 0.0 & 0.0 & 0.0 & 0.0 & 0.0 & 0.0 & 0.0 & 0.0 & 0.0 & 0.0 & 0.0 & 0.0 & 0.0 \\
\hline \multicolumn{15}{|l|}{$R 50$} \\
\hline $\mathrm{Z}$ & -1.4 & 0.4 & -0.9 & 0.0 & -1.3 & -0.9 & -0.7 & 0.2 & 0.4 & -0.4 & -0.4 & -0.8 & 0.4 & 0.0 \\
\hline Q & -0.1 & 0.0 & 0.0 & 0.0 & -0.1 & 0.0 & 0.0 & 0.0 & 0.0 & 0.0 & 0.0 & 0.0 & 0.0 & 0.0 \\
\hline \multicolumn{15}{|l|}{$R 100$} \\
\hline Z & -0.4 & -0.6 & 0.0 & 0.4 & -0.7 & -0.6 & -0.8 & -0.5 & -0.7 & 0.0 & -0.8 & -0.6 & -0.6 & -0.4 \\
\hline $\mathrm{Q}$ & 0.0 & 0.0 & 0.0 & 0.0 & 0.0 & 0.0 & 0.0 & 0.0 & 0.0 & 0.0 & 0.0 & 0.0 & 0.0 & 0.0 \\
\hline
\end{tabular}

Singnificant negative trends at 0.05 level are bold-italic while significant positive trends at 0.05 level are bold 
It is observed that there have been rapid decreasing trends in the total annual precipitation (PRCPTOT) in all the subwatersheds. This is an indication of diminishing water resource potential in the region. This particular finding is in agreement with the village survey conducted in 2016 by the first author regarding the hydrometeorological conditions and agricultural activities in the study area. During the survey, the participants were asked about the water flow regime of the Pare River. Most of the participants claimed diminishment of water level depths at various sections of the Pare River. The reason behind may be due to decrease in rainfall in the study area since there are no structures such as reservoirs, dams, etc. which can regulate the flow. Further, the statistically significant decreasing trends in the consecutive wet days (CWD) and increasing trends in the consecutive dry days (CDD) also suggest and support the diminishing water resource potential in the study area. Our finding also agrees with the results of the studies conducted by Rupakumar et al. (1992), Bhagawati et al. (2016), Patle et al. (2016) and Bhagawati et al. (2017) over the regions in which this study area is situated. Their findings illustrated decrease in annual total precipitation as well as monsoonal precipitation approximately during the same historical period in this study.

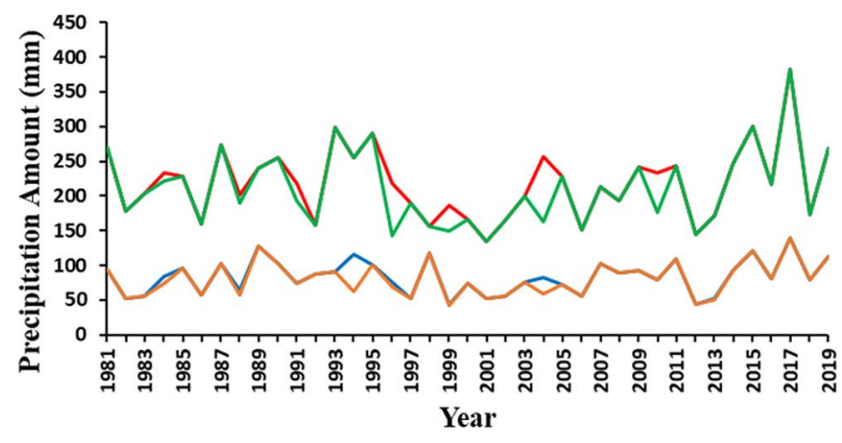

RX1DAY - RX5DAY - RX1DAY (monsoon) - RX5DAY(monsoon)
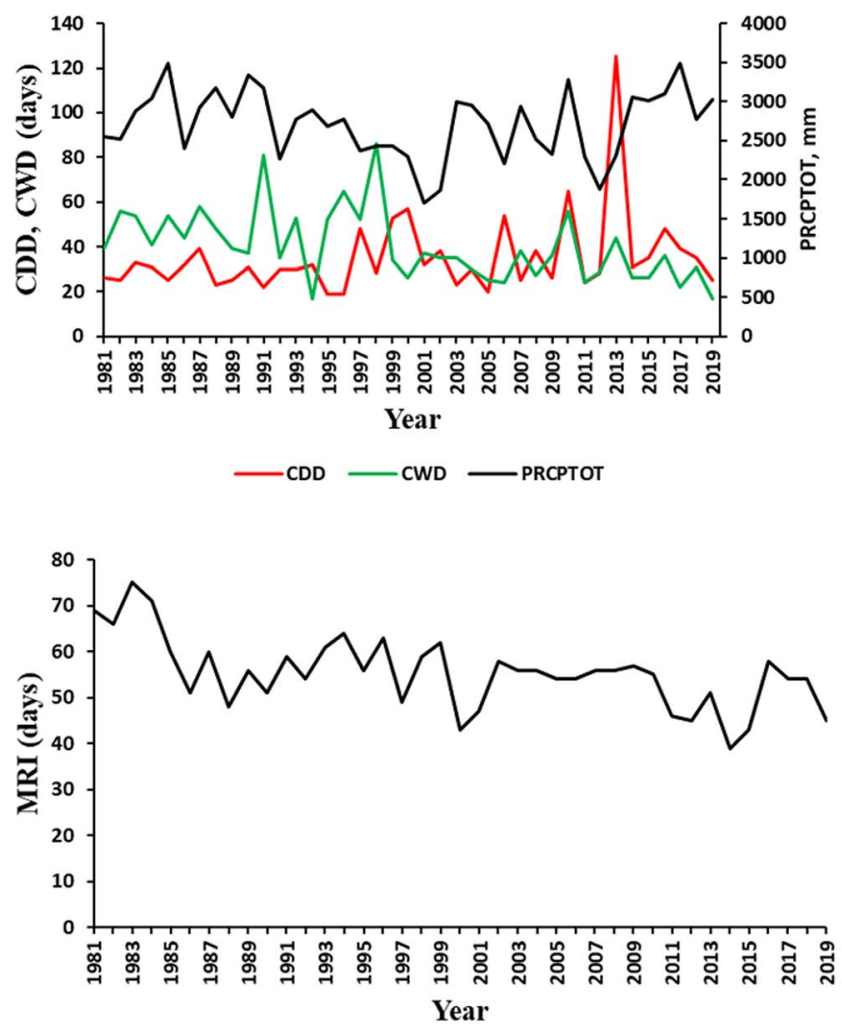
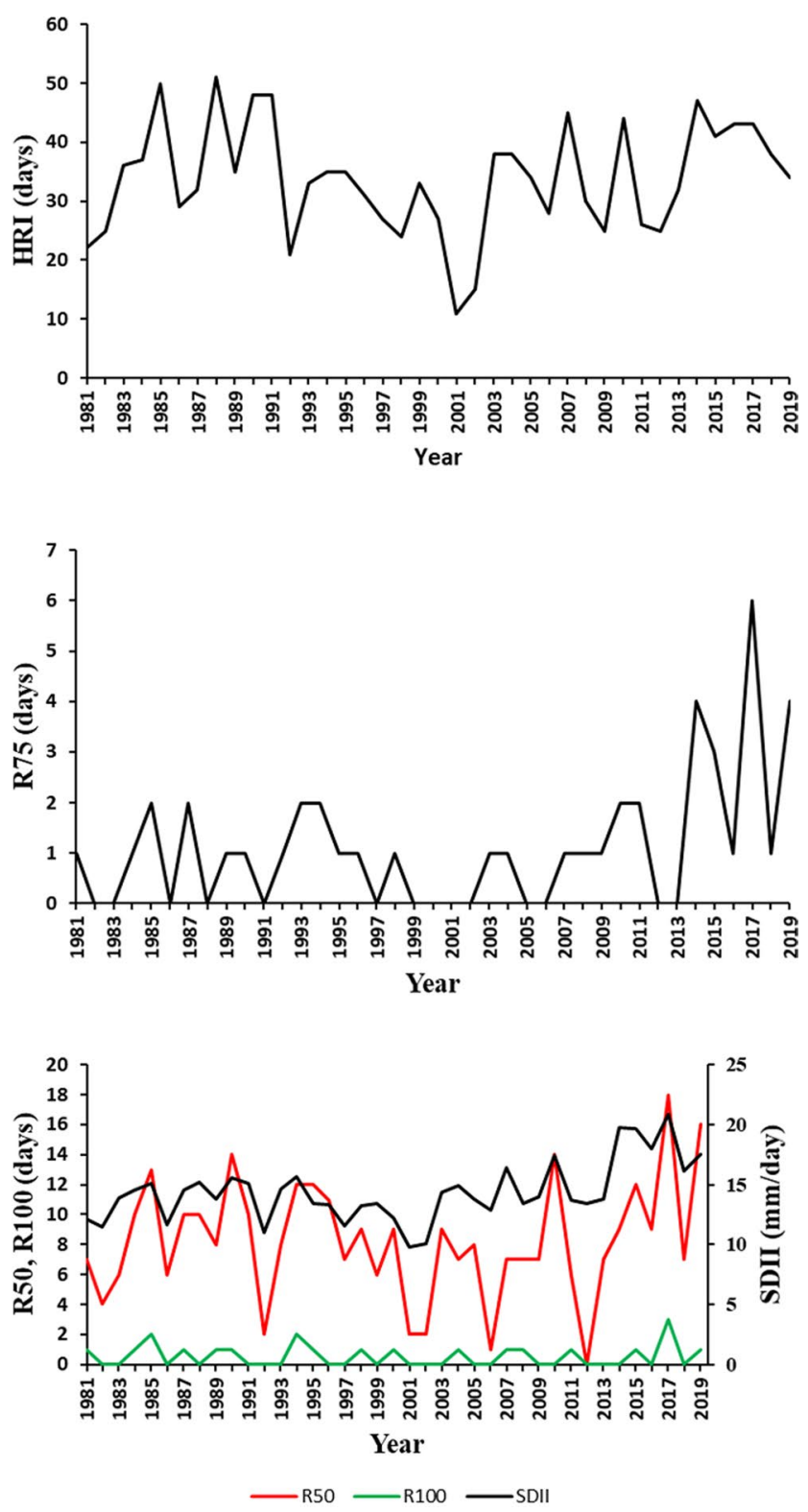

Fig. 4 RX1DAY, RX5DAY, RX1DAY (monsoon), RX5DAY (monsoon), CDD, CWD, PRCPTOT, MRI, HRI, R50, R75, R100 and SDII of Pare watershed for the period of 1981-2019 
In order to have a clear visualization of how the precipitation indices such as RX1DAY, RX5DAY RX1DAY (monsoon), RX5DAY (monsoon), CDD, CWD, MRI, HRI, R75, R50, R100 and SDII have evolved through time from 1981 to 2019, graphs are plotted for Pare watershed, as shown in Fig. 4. The results of the trend analysis and the graphs shown in Fig. 4 suggest that the precipitation regime in the study area had been accompanied by overall reduction in precipitation amount, milder rainfall events, reduction in monsoon (June-September) rainfall and drier climatic conditions. This study found that there were few years in the study area when the rainfall in any day of the year is less than $75 \mathrm{~mm}$ as indicated by R75 and R100. More than $50 \%$ (22 years of 39 years) of the total years of study have singleday rainfall amount of less than $100 \mathrm{~mm}$. Also, the singleday precipitation amount in the year 2012 is found less than $50 \mathrm{~mm}$ as indicated by R50 in Fig. 4. The results suggest that precipitation events are becoming milder in the region and the decreasing magnitude values of trends in precipitation total in almost all the subwatersheds suggest harmful consequences associated with the shortage of water in the years to come.

\section{Projected precipitation extremes for the period of 2021-2050}

The Mann-Kendall test $Z$ and Sen's slope $Q$ values for different extreme precipitation indices under RCP 4.5 and RCP 8.5 (not shown in this paper) are found statistically insignificant at 0.05 level except a case in moderate rainfall index (MRI) at the subwatershed SW10 under RCP 8.5. The MRI at SW10 under RCP 8.5 showed decreasing trend, significant at 0.05 level. Again, both scenarios of RCPs predicted the trends as well as the extreme indices in a very similar way. The projected future precipitation extremes under both RCP scenarios suggest that the study area can expect further diminishing pattern in the precipitation amount, milder rainfall events as well as reduction in monsoon rainfall. By looking at the results from the historical period (1981-2019), we can say that under these two scenarios, the precipitation conditions leading to water resource potential of the study area will be exacerbated in the future. Overall, the trends of the projected precipitation extremes under RCP 4.5 and 8.5 scenarios cannot give a conclusive future precipitation regime due to mixed direction of trends and their insignificant nature. In order to have clearer picture of future precipitation regimes in the area, the precipitation extremes of the historical and both the scenarios are plotted as shown in Fig. 5.

As illustrated in the graphs, we can see that there were various years in which the RX1DAY (monsoon) and RX5DAY (monsoon) are less than the annual RX1DAY and RX5DAY values, respectively. These showed that the 1-day and 5-day rainfall maximum did not occur during the monsoon season. For example, in the year 1994, the RX1DAY (annual maximum 1-day rainfall) is $116 \mathrm{~mm}$, while its annual 1-day maximum rainfall during monsoon [RX1DAY (monsoon)] is $62 \mathrm{~mm}$ only. There is a huge gap between the annual maximum and monsoon maximum values indicating that the monsoon rainfall had greatly reduced. Another example for the same period is in the year 2004, when the RX5DAY and RX5DAY (monsoon) values are 257 and $162 \mathrm{~mm}$, respectively. In this year, the RX1DAY and RX1DAY (monsoon) values also differ from each other. In case of RCP 4.5 and 8.5 scenarios, even though the gaps between their respective annual and monsoon maximums are smaller, more such cases are observed indicating lesser monsoon rainfall. In another perspective, we can conclude that more temporal spread, outside of the monsoon season, of extreme events can be expected in the future. The locals anticipated reduction in water resource potential in the study area and is evident from the decreasing pattern of monsoon rainfall as well as annual total precipitation.

Further analysis of the annual rainfall (PRCPTOT) and monsoon rainfall for historical period, RCP 4.5 and RCP 8.5 scenarios showed that the percentage departures of the monsoon from its annual total had increased in RCP 4.5 and RCP 8.5 scenarios. The mean departure of the monsoon rainfall from its annual values over the historical, RCP 4.5 and RCP 8.5 is found as $30 \%, 51 \%$ and $52 \%$, respectively. The graphs of the simple daily intensity index (SDII) and consecutive wet days have clearly shown that they are expected to be reduced greatly during the period of 2021-2050. The mean SDII during historical period is found as approximately $14.5 \mathrm{~mm} /$ day, while it is expected to reduce to merely $10 \mathrm{~mm} /$ day in the future period under RCPs 4.5 and 8.5. Similarly, for consecutive wet days, it is expected at around an average of 11 days in both the RCPs to be reduced from mean consecutive wet days of around 40 days during the historical period. As per the graph of CDD for all the periods considered in this study, both RCPs, although decreased, do not differ much. The mean values of CDD in historical, RCP 4.5 and RCP 8.5 scenarios are, respectively, 35, 28 and 26 days (approx.). The conditions of days having moderate rainfall (rainfall in between 10 and $25 \mathrm{~mm}$ ) as indicated by MRI in Fig. 5 are expected to reduce from mean value of 55 days a year in the historical period to about approximately 31 days a year in RCPs 4.5 and 8.5 scenarios during 2021-2050. Similarly, the condition of high rainfall days (rainfall in between 25 and $75 \mathrm{~mm}$ ) as indicated by HRI in Fig. 5 is also expected to be reduced in RCP 4.5 (12 days a year) and RCP 8.5 (13 days a year) from the historical period which is approximately having a mean value of 34 days a year. From the graph of R75 in Fig. 5, the higher frequency of zero values in the RCP scenarios as compared to the historical period indicated that the extreme events of 

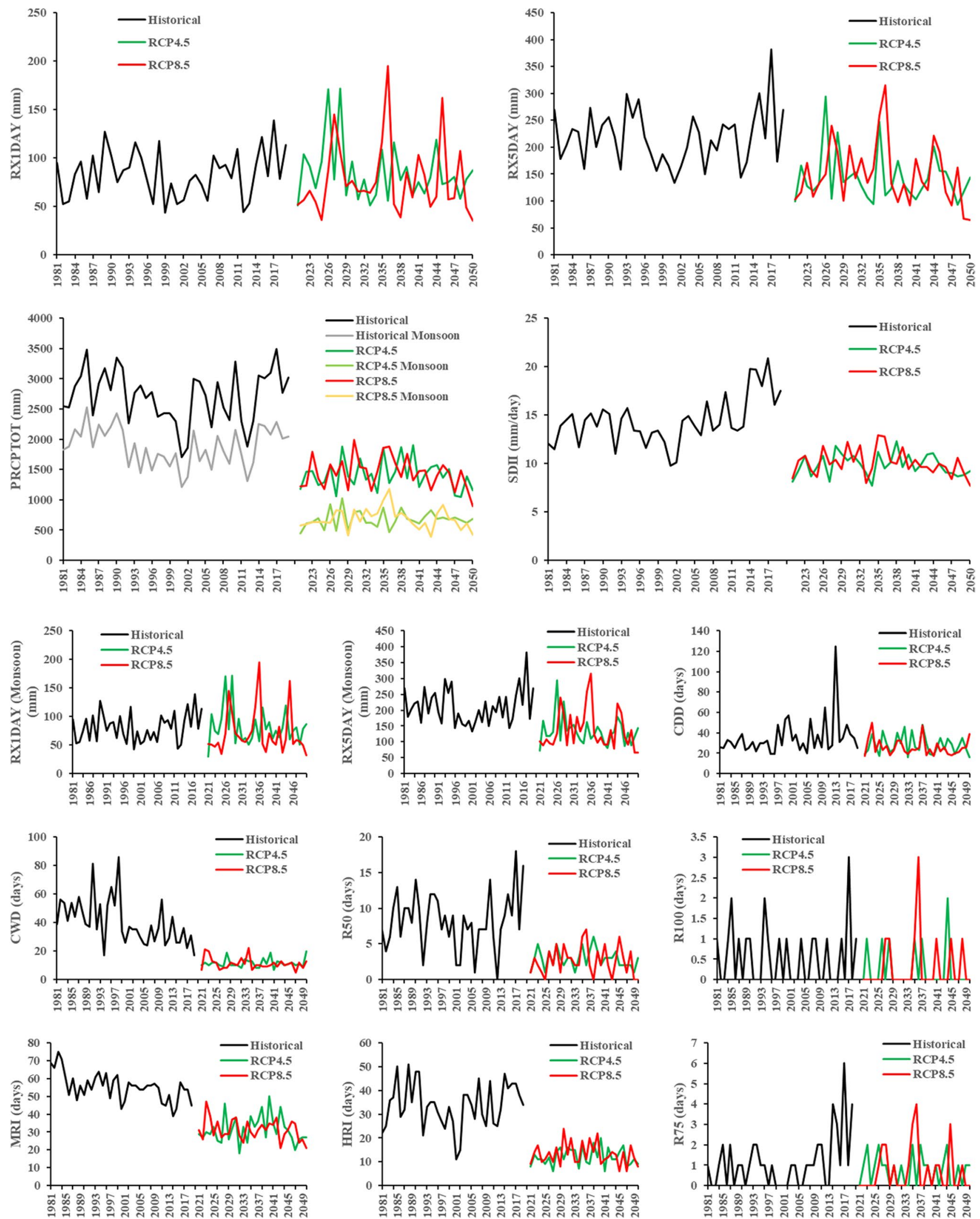

Fig. 5 Precipitation extremes for historical (1981-2019), RCP 4.5 scenario (2021-2050) and RCP 8.5 scenario (2021-2050) 
very high rainfall in a day are also expected to occur less in the future period of 2021-2050. The R50 index is also expected to reduce from 8 days a year during 1981-2019 to a merely 3 days a year during 2021-2050. The study also found R100 index in the study area to be reduced in the future. As observed in Fig. 5, magnitude of all the graphs is attenuated in future scenarios as compared to the historical period. This suggests that the study area is expected to receive lesser annual and monsoon rainfall; reduced peaks of consecutive rainfall amounts; lower rainfall intensity; lesser consecutive days of dry as well as wet days; and also lesser number of days having heavy precipitation amount in a day.

The study area, Pare watershed, is situated in a remote place where long-term station rainfall records are not available. Therefore, the study adopted the interpolated gridded observed data from IMD at a spatial resolution of approximately $25 \mathrm{~km}$ by $25 \mathrm{~km}$. The application of coarse resolution of the rainfall data in the comparatively small size watershed does not allow to capture the orographic effects of rainfall which is prevalent in the study area. This unaccounted effect may have impacted the results to some extent; however, the results of this study can be deemed satisfactory by looking at the results of some earlier studies mentioned above. Some value addition work can be done in this research like extending the time period of analysis for both historical and future periods so as to check the presence of trends at a longer time period. Also, different spatial interpolators which can account for the orographic effect of precipitation can be tried other than IDW technique which used only the distances between grid points as a driving variable to interpolate precipitation for each subwatershed. It is worth to mention that in a remote place, where the data are scarce or long-term records are not available, using gridded data from either interpolated observed data or simulated climatic satellite data can be a good option to know the climatic regime of the place. Therefore, various other such data from different sources with finer spatial resolution can be adopted in the study area to compare with the findings of this study as well as to make statements on the suitability of the other data in the region.

\section{Conclusions}

This study was carried out to investigate various precipitation extremes in Pare watershed of Arunachal Pradesh, India, for historical period of 39 years (1981-2019) and future period of 30 years (2021-2050) under two projected climate scenarios of RCP 4.5 and RCP 8.5. In this study, various tools such as ArcGIS, MATLAB, Python and Microsoft Excel were used to prepare input data and analysis of the results. RClimDex software was used to compute various precipitation extremes. The watershed was divided into 13 subwatersheds to see the spatial variation of precipitation extreme indices; however, it observed no significant spatial variation among the subwatersheds. Majority of the precipitation extreme indices indicated decreasing trends, and most of them are not statistically significant at $95 \%$ confidence level. Trends in extreme precipitation indices such as SDII, CWD, MRI and CDD are found significant. The CDD showed increasing trends with one statistically significant in one subwatershed (SW7) at the rate of 0.3 days per year. The trend analysis of the extreme precipitation indices over the whole watershed indicated significant decreasing trends for CWD and MRI while following a significant increasing trend for SDII. The two scenarios of the future projected in this study indicate very similar extreme precipitation indices. Of all the future indices, only one case in the subwatershed, SW10, is expected to have significant decrease in annual counts of days when rainfall is between 10 and $25 \mathrm{~mm}$. The results of the historical period suggest that the precipitation regime in the study area had been accompanied by overall reduction in precipitation amount, milder rainfall events, reduction in monsoon (June-September) rainfall and drier climatic conditions. And the results of both RCP scenarios suggest that the study area can expect further diminishing pattern in the precipitation amount, milder rainfall events as well as reduction in monsoon rainfall. The authors concluded that with the prevalent historical scenario and future projected scenarios of the extreme precipitation indices, the water resource potential in the study area is expected to be greatly reduced bringing needs for construction of water conservation structures in order to sustain agricultural activities.

Funding The authors received no specific funding for this work.

Availability of data and materials The data used in the research are from the public domain.

\section{Declarations}

Conflict of interest The research work is done within the capabilities of the authors and not associated with any private organization, so the conflict of interest is absent.

Ethical approval The data used in the research are from the public domain; therefore, there is no need for ethical approval. The manuscript is not submitted to any other journal before submission to this journal and further not submitted simultaneously to another journal.

Open Access This article is licensed under a Creative Commons Attribution 4.0 International License, which permits use, sharing, adaptation, distribution and reproduction in any medium or format, as long as you give appropriate credit to the original author(s) and the source, provide a link to the Creative Commons licence, and indicate if changes were made. The images or other third party material in this article are included in the article's Creative Commons licence, unless indicated 
otherwise in a credit line to the material. If material is not included in the article's Creative Commons licence and your intended use is not permitted by statutory regulation or exceeds the permitted use, you will need to obtain permission directly from the copyright holder. To view a copy of this licence, visit http://creativecommons.org/licenses/by/4.0/.

\section{References}

Aggarwal PK (2008) Global climate change and Indian agriculture: impacts, adaptation and mitigation. Indian J Agric Sci 78(10). http://www.indiaenvironmentportal.org.in/files/Global\%20Cli mate\%20Change.pdf

Al-Habsi M, Gunawardhana L, Al-Rawas G (2014) Trend analysis of climate variability in Salalah, Oman. Int J Stud Res Technol Manag 2(05):168-171. https://giapjournals.com/ijsrtm/article/ view/132/126

Badsha MAH, Kafi MAH, Islam MZ, Islam T (2016) Analysis of the trends in temperature and precipitation variables for Sylhet city of Bangladesh using RClimDex toolkit. In: Proceedings of the 3rd international conference on civil engineering for sustainable development (ICCESD), 12-14 February 2016, KUET, Khulna

Bandyopadhyay A, Nengzouzam G, Singh WR, Hangsing N, Bhadra A (2018) Comparison of various re-analyses gridded data with observed data from meteorological stations over India. In: EPiC series in engineering, vol 3: 190-198. HIC 2018. 13th international conference on hydroinformatics. https://easychair.org/publi cations/paper/bXLw

Bhagawati K, Bhagawati R, Sen A, Shukla KK, Alone RA (2016) Rainfall trend and variability analysis of subtropical hills of Arunachal Pradesh in Northeastern Himalayan Region of India. Curr World Environ 11(2):631-636

Bhagawati R, Bhagawati K, Jini D, Alone RA, Singh R, Chandra A, Makdoh B, Sen A, Shukla KK (2017) Review on climate change and its impact on agriculture of Arunachal Pradesh in the Northeastern Himalayan Region of India. Nat Environ Pollut Technol 16(2):535-539

Dore MHI (2005) Climate change and changes in global precipitation patterns: What do we know? Environ Int 31(8):1167-1181. https://doi.org/10.1016/j.envint.2005.03.004

Dubey SK, Sharma D (2018) Spatio-temporal trends and projections of climate indices in the Banas River Basin, India. Environmental Processes. https://doi.org/10.1007/s40710-018-0332-5

Eckstein D, Hutfils ML, Winges M (2019) Global climate risk index 2019: Who suffers most from extreme weather events? Weatherrelated Loss Events in 2017 and 1998 to 2017. https://germa nwatch.org/sites/germanwatch.org/files/Global\%20Climate\% 20Risk\%20Index\%202019_2.pdf

Eckstein D, Künzel V, Schäfer L (2018) Global climate risk index 2018 Who Suffers Most from Extreme Weather Events? Weatherrelated Loss Events in 2016 and 1997 to 2016. https://reliefweb. int/sites/reliefweb.int/files/resources/20432.pdf

Ehret U, Zehe E, Wulfmeyer V, Warrach-Sagi K, Liebert J (2012) HESS opinions "Should we apply bias correction to global and regional climate model data?” Hydrol Earth Syst Sci 16:33913404. https://doi.org/10.5194/hess16-3391-2012

Gosain AK, Rao S, Basuray D (2006) Climate change impact assessment on hydrology of Indian river basins. Curr Sci 90:346-353

Guan Y, Zhang X, Zheng F, Wang B (2015) Trends and variability of daily temperature extremes during 1960-2012 in the Yangtze River basin, China. Global Planet Change 124:79-94

Keggenhoff I, Elizbarashvili M, Amiri-Farahani A, King L (2014) Trends in daily temperature and precipitation extremes over Georgia, 1971-2010. Weather Climate Extremes 4:75-85
Kendall MG (1975) Rank correlation methods, 4th edn. Charles Griffin, London

Kim BS, Yoon YH, Lee HD (2011) Analysis of changes in extreme weather events using extreme indices. Environ Eng Res 16(3): 175-183

Kothawale DR, Revadekar JV, Kumar KR (2010) Recent trends in premonsoon daily temperature extremes over India. J Earth Syst Sci 119(1):51-65

Kumar D, Dimri AP (2018) Regional climate projections for Northeast India: an appraisal from CORDEX South Asia experiment. Theor Appl Climatol 134:1065-1081. https://doi.org/10.1007/ s00704-017-2318-z

Mann HB (1945) Non-parametric test against trend. Econometrica $13: 245-259$

Maraun D, Widmann M (2018) Statistical downscaling and bias correction for climate research. Cambridge University Press, Cambridge

Mirza MMQ (2003) Climate change and extreme weather events: can developing countries adapt? Clim Pol 3(3):233-248

Obasi GOP (1994) WMO's role in the international decade for natural disaster reduction. Bull Am Meteor Soc 75(9):1655-1661. https:// doi.org/10.1175/1520-0477(1994)075\%3c1655:WRITID\%3e2.0. $\mathrm{CO} ; 2$

Patle GT, Libang A, Ahuja S (2016) Analysis of rainfall and temperature variability and trend detection: a non parametric Mann Kendall test approach. In: 3rd international conference on computing for sustainable global development (INDIACom), New Delhi, pp 1723-1727. http://ieeexplore.ieee.org/stamp/stamp.jsp?tp=\& arnumber $=7724562 \&$ isnumber $=7724213$

Patra JP, Mishra A, Singh R, Raghuwanshi NS (2012) Detecting rainfall trends in twentieth century (1871-2006) over Orissa state. India Climate Change 111(3):801-817

Plummer N, Salinger MJ, Nicholls N, Suppiah R, Hennessy KJ, Leighton RM, Trewin B, Page CM, Lough JM (1999) Changes in climate extremes over the Australian region and New Zealand during the twentieth century. Clim Change 42(1):183-202

Rajeevan M, Bhate J, Jaswal AK (2008) Analysis of variability and trends of extreme rainfall events over India using 104 years of gridded daily rainfall data. Geophys Res Lett 35(18):L1870

Rathjens H, Bieger K, Srinivasan R, Chaubey I, Arnold JG (2016) CMhyd user manual. https://swat.tamu.edu/media/115265/bias_ cor_man.pdf. Accessed on 10 May 2020

Revadekar JV, Kothawale DR, Patwardhan SK, Pant GB, Rupakumar $\mathrm{K}$ (2012) About the observed and future changes in temperature extremes over India. Nat Hazards 60:1133-1155

Roy SS, Balling RC (2004) Trends in extreme daily precipitation indices in India. Int J Climatol 24(4):457-466

Rupakumar K, Pant GB, Parthasarthy B, Sonatak NA (1992) Spatial and sub seasonal pattern of the long term trends of Indian summer monsoon ra infall. Int J Climatol 12:257-268

Salmi T, Määttä A, Anttila P, Ruoho-Airola T, Amnell T (2002) Detecting trends of annual values of atmospheric pollutants by the mannkendall test and sen's slope estimates the excel template application MAKESENS. Publications on air quality, volume 31, Finnish Meteorological Institute: Helsinki

Santos CAC, Oliveira VG (2017) Trends in extreme climate indices for Para State. Braz Rev Bras Meteorol 32(1):13-24

Sen PK (1968) Estimates of regression coefficient based on Kendall's tau. J Am Stat Assoc 39:1379-1389

Shrestha AB, Bajracharya SR, Sharma AR, Duo C, Kulkarni A (2017) Observed trends and changes in daily temperature and precipitation extremes over the Koshi river basin 1975-2010. Int J Climatol 37(2):1066-1083

Singh D, Gupta RD, Jain SK (2015) Study of daily extreme temperature indices over Sutlej Basin, NW Himalayan region. India Global Nest J 17(2):301-311 
Tirkey AS, Ghosh M, Pandey AC, Shekhar S (2018) Assessment of climate extremes and its long term spatial variability over the Jharkhand state of India. Egypt J Remote Sens Space Sci 21(1):49-63

Toure HA, Kalifa T, Kyei-Baffour N (2017) Assessment of changing trends of daily precipitation and temperature extremes in Bamako and Segou in Mali from 1961-2014. Weather Climate Extremes $18: 8-16$
Zhang X, Yang F (2004) RClimDex (1.0)-user manual. Climate research branch environment Canada, Downsview, Ontario. http:// ensembles-eu.metoffice.com/C3S-DR/pages/workshop_tools/ RClimDexUserManual.pdf

Publisher's Note Springer Nature remains neutral with regard to jurisdictional claims in published maps and institutional affiliations. 